\title{
Stathmin is key in reversion of doxorubicin resistance by arsenic trioxide in osteosarcoma cells
}

\author{
TAO FENG ${ }^{1}$, GUANGLEI QIAO ${ }^{1}$, LI FENG $^{2}$, WEIXIANG QI $^{1}$, YUJING HUANG ${ }^{1}$, YANG YAO ${ }^{1}$ and ZAN SHEN $^{1}$ \\ ${ }^{1}$ Department of Oncology, Affiliated People's 6th Hospital, Shanghai Jiaotong University, Shanghai 200233; \\ ${ }^{2}$ Department of Pharmacy, The Donggang People's Hospital, Rizhao, Shandong 276800, P.R. China
}

Received December 2, 2013; Accepted June 26, 2014

DOI: $10.3892 / \mathrm{mmr} .2014 .2618$

\begin{abstract}
Osteosarcoma is the most common type of malignant bone tumor in children and adolescents. Numerous patients are unable to be cured due to the development of resistance of the osteosarcoma cells to chemotherapeutic drugs. Therefore, reversion of drug resistance is urgently required for the treatment of osteosarcoma. Arsenic trioxide $\left(\mathrm{As}_{2} \mathrm{O}_{3}\right)$ is an active ingredient in Traditional Chinese Medicine, but the therapeutic potential of $\mathrm{As}_{2} \mathrm{O}_{3}$ in osteosarcoma remains largely unexplored. The current study investigated the effects of $\mathrm{As}_{2} \mathrm{O}_{3}$ on MG63 osteosarcoma cells using a cell proliferation assay, flow cytometric analysis of the cell cycle and cell apoptosis, reverse transcription polymerase chain reaction to detect stathmin mRNA expression levels and western blot analysis to detect the stathmin protein expression levels. $\mathrm{As}_{2} \mathrm{O}_{3}$ and doxorubicin (ADM) combination treatment markedly inhibited cell proliferation in ADM-resistant MG63 (MG63/dox) osteosarcoma cells, clearly induced G2/M phase cell cycle arrest and increased the number of apoptotic MG63/dox cells. Furthermore, stathmin expression was found to be downregulated in MG63/dox cells and was sensitive to ADM treatment. Additional investigation revealed that the downregulation of stathmin expression in MG63/dox cells by stathmin small interfering RNA significantly enhanced the reversion of ADM resistance in MG63/dox by $\mathrm{As}_{2} \mathrm{O}_{3}$. The data indicated that $\mathrm{As}_{2} \mathrm{O}_{3}$ reversed ADM resistance in MG63/dox cells through downregulation of stathmin and may be a potential drug for the treatment of ADM-resistant osteosarcoma.
\end{abstract}

\section{Introduction}

Osteosarcoma is an aggressive type of cancer commonly observed in adolescents and children. With the introduction of

Correspondence to: Professor Zan Shen or Professor Yang Yao, Department of Oncology, Affiliated People's 6th Hospital, Shanghai Jiaotong University, Shanghai 200233, P.R. China

E-mail: flyicefish@163.com

E-mail: xinyifeng384@gmail.com

Key words: arsenic trioxide, osteosarcoma, multidrug resistance, stathmin, apoptosis intensive chemotherapy, the cure rate of patients with localized osteosarcoma has improved from 15 to $20 \%$, and achieved to $\sim 70 \%$ with surgery alone (1). Nonetheless, approximately one-third of osteosarcoma patients experience recurrent or progressive disease, of which the majority of cases are due to the development of resistance to chemotherapeutic drugs by the osteosarcoma cells (2). Therefore, drug resistance has been a hindrance in achieving improved cure rates.

Arsenic trioxide $\left(\mathrm{As}_{2} \mathrm{O}_{3}\right)$ compounds have been used in Traditional Chinese Medicine for thousands of years. The therapeutic use of these compounds in acute promyelocytic leukemia (APL) was described in the 1970s. In addition to APL, $\mathrm{As}_{2} \mathrm{O}_{3}$ has been effective in the treatment of certain solid tumors, such as gastric cancer, lung cancer, breast cancer and hepatocellular carcinoma $(3,4)$. Studies have demonstrated that $\mathrm{As}_{2} \mathrm{O}_{3}$ induced cytotoxic effects in these tumors in a dose- and time-dependent manner (5). However, the detailed mechanisms of $\mathrm{As}_{2} \mathrm{O}_{3}$ cytotoxicity remain to be further elucidated.

Stathmin is a microtubule regulatory phosphoprotein that is important in the assembly of the mitotic spindle. Stathmin is a key regulator of the microtubule network and provides an attractive therapeutic target in cancer treatment $(6,7)$. Previous studies have demonstrated that small interfering (si)RNA or antisense-mediated downregulation of stathmin expression may result in proliferation inhibition and chemosensitivity enhancement in human osteosarcoma cells $(8,9)$.

In the present study, the effect of $\mathrm{As}_{2} \mathrm{O}_{3}$ on MG63 human doxorubicin-resistant osteosarcoma cells was examined, along with the molecular mechanisms of the effects. The present study was conducted by analyzing the effects of $\mathrm{As}_{2} \mathrm{O}_{3}$ on cell proliferation, cell apoptosis, and stathmin mRNA and protein expression levels in MG63 and MG63/dox human osteosarcoma cells.

\section{Materials and methods}

Regents. $\mathrm{As}_{2} \mathrm{O}_{3}$ was obtained from ShuangLu Pharmaceutical Co., Ltd. (Beijing, China), doxorubicin (ADM) was provided by Pfizer Pharmaceuticals Corporation (New York, NY, USA), propidium iodide (PI) was purchased from Sigma-Aldrich (St. Louis, MO, USA), Cell Counting Kit-8 (CCK-8) was obtained from Dojindo Laboratories (Kumamoto, Japan), rabbit monoclonal antibody against stathmin was purchased from Abgent (1:5,000, San Diego, CA, USA) and antibody 
against $\beta$-actin was purchased from CoWin Bioscience Co., Ltd. (Beijing, China).

Cell lines. The MG63 human osteosarcoma parental cell line was obtained from the Institute of Biochemistry and Cell Biology, Chinese Academy of Sciences (Shanghai, China). The MG63/dox human multidrug-resistant (MDR) osteosarcoma cell line with P-glycoprotein overexpression, which was selected in a step-wise manner through exposing drug-sensitive MG63 cells to increasing doses of ADM, was provided by Dr Yoshio Oda (Graduate School of Medical Sciences, Kyushu University, Fukuoka, Japan). These cell lines were grown in high-glucose Dulbecco's modified Eagle's medium (DMEM; Hyclone, Logan, Utah, USA) supplemented with $10 \%$ fetal bovine serum (FBS; Hyclone), 100 units/ml penicillin and $100 \mathrm{~g} / \mathrm{ml}$ streptomycin (Gibco-BRL, Carlsbad, CA, USA) at $37^{\circ} \mathrm{C}$ in a humidified $5 \% \mathrm{CO}_{2}$ atmosphere.

Cell proliferation assay. The cells were diluted with standard culture medium to a seeding density of $5 \times 10^{3}$ cells/well, suspended in 96 -well plates $\left(100 \mu \mathrm{l} /\right.$ well) and incubated at $37^{\circ} \mathrm{C}$ for $6 \mathrm{~h}$. Subsequently, the cells were incubated for 24 or $48 \mathrm{~h}$ in the absence or presence of various concentrations of ADM and $\mathrm{As}_{2} \mathrm{O}_{3}$. Cells without any anticancer agent treatment served as a negative control. Cell proliferation was evaluated by CCK- 8 assay. Briefly, $10 \mu$ l CCK-8 solution was added to each well containing $100 \mu \mathrm{l}$ DMEM. Following incubation at $37^{\circ} \mathrm{C}$ for $4 \mathrm{~h}$, the plates were analyzed on a Multiskan MK3 ELISA reader (Thermo Scientific, Madison, WI, USA) at $450 \mathrm{~nm}$.

Cell cycle analysis. The distribution of cells in the different phases of the cell cycle was analyzed by PI staining of fixed whole cells. The cells were incubated for $48 \mathrm{~h}$ with $\mathrm{As}_{2} \mathrm{O}_{3}(2 \mu \mathrm{M})$ and $\mathrm{ADM}(200 \mathrm{ng} / \mathrm{ml})$ and as indicated. A total of $\sim 1 \times 10^{6}$ cells were harvested, washed and fixed in $70 \%$ cold alcohol overnight at $-20^{\circ} \mathrm{C}$. The fixed cells were washed in phosphate-buffered saline (PBS) and resuspended in $1 \mathrm{ml}$ PI solution (PBS containing $0.05 \mathrm{mg} / \mathrm{ml} \mathrm{PI} \mathrm{and} 1 \mathrm{mg} / \mathrm{ml}$ RNase). The cells were incubated for $30 \mathrm{~min}$ at $37^{\circ} \mathrm{C}$. DNA content was analyzed within $2 \mathrm{~h}$ using a FACSCalibur flow cytometer (Becton-Dickinson, Franklin Lakes, NJ, USA) at $488 \mathrm{~nm}$ single laser excitation. The cell-cycle distribution was analyzed using Lysis II software (Becton-Dickinson).

Cell apoptosis assay. Apoptotic cells were detected by flow cytometry with Annexin V-fluorescein isothiocyanate (FITC)/PI dual staining (Invitrogen Life Technologies, Carlsbad, CA, USA). The assay was performed following the manufacturer's instructions. The emitted green Annexin V fluorescence and red PI fluorescence were detected by the flow cytometer with an excitation wavelength of $488 \mathrm{~nm}$ and emission wavelengths of 525 and $575 \mathrm{~nm}$, respectively. For each sample, 10,000 events were recorded. The quantities of cells in early apoptosis, late apoptosis and necrosis were determined as the percentages of Annexin V+/PI-, Annexin V+/PI+ and Annexin V-/PI+ cells, respectively.

Reverse transcription polymerase chain reaction (RT-PCR). The harvested cells were washed with PBS and total RNA was extracted from cells using TRIzol reagent (Invitrogen
Life Technologies). RNA purity (A260/A280 >1.8) was verified using a spectrophotometer, and RNA integrity was confirmed by visualization of $28 \mathrm{~S}$ and $18 \mathrm{~S}$ bands (2:1) on a $1 \%$ agarose gel. RNA $(1 \mu \mathrm{g})$ was used to synthesize cDNA using Superscript First-Strand Synthesis kit (Fermentas, Waltham, MA, USA) following the manufacturer's instructions. The stathmin mRNA expression levels were detected by PCR using the following specific primers: Stathmin sense, 5'-TCC AAT CTG CAT TGA TTA CCTG-3'; and antisense, 5 '-CTT CCT TCC TAA GGT CCC ACTT-3'. Human $\beta$-actin served as an internal loading control; the primers used were as follows: $\beta$-actin sense, 5 '-CCA GCC GAG CCA CAT CGC TC-3'; and $\beta$-actin antisense, 5'-ATG AGC CCC AGC CTT CTC CAT-3'.

Quantitative (q)PCR. Total RNA was extracted using TRIzol and quantified by spectrophotometry. Following the reverse transcription reaction, $1 \mu \mathrm{l} \mathrm{cDNA}$ served as a template.

qPCR was then performed using Platinum SYBR Green qPCR SuperMix (Takara, Dalian, China) and the ABI Prism 7500 Sequence Detection system. The primer sequences used were as follows: $\beta$-actin sense, 5'-GGC GGC ACC ACC ATG TAC CCT-3' and antisense, 5'-AGG GGC CGG ACT CGT CAT ACT-3'. The stathmin primer (P162495) was purchased from Shanghai Bioneer Company (Shanghai, China). Amplification conditions were as follows: $95^{\circ} \mathrm{C}$ for $10 \mathrm{~min}$, and then 40 cycles at $95^{\circ} \mathrm{C}$ for $15 \mathrm{sec}, 60^{\circ} \mathrm{C}$ for $60 \mathrm{sec}$ and $72^{\circ} \mathrm{C}$ for $60 \mathrm{sec}$. The specificity of detected signals was confirmed by a dissociation curve consisting of a single peak. All samples from each experiment were run in duplicate. The fold change of stathmin small interfering (si)RNA transcript levels between the indicated group and the control equals $2^{-\Delta \Delta C t}$, where $\Delta$ Cycle threshold $(\mathrm{Ct})=\mathrm{Ct}$ siRNA $-\mathrm{Ct}$ Actin and $\Delta \Delta \mathrm{Ct}=\Delta \mathrm{Ct}$ indicated group $-\Delta \mathrm{Ct}$ control.

Western blot analysis. The harvested cells were washed with PBS twice and lysed in RIPA lysis buffer (Beyotime Institute of Biotechnology, Jiangsu, China) on ice. The cell extracts were clarified by centrifugation and protein concentrations were determined using an Evolution 60S UV-Visible spectrophotometer (Thermo Scientific). Each protein extract $(30 \mu \mathrm{g})$ was purified by $12 \%$ SDS-PAGE followed by western blot analysis using the antibodies against stathmin and $\beta$-actin, respectively.

Indirect immunofluorescence assay. Slide-cultured MG63/dox cells were incubated with $\mathrm{ADM}$ and $\mathrm{As}_{2} \mathrm{O}_{3}$ as indicated. At $48 \mathrm{~h}$ after incubation, the cells were fixed in $4 \%$ paraformaldehyde at room temperature for $30 \mathrm{~min}$. The slides were washed in PBS and then permeabilized by $0.1 \%$ Triton X-100 at $4^{\circ} \mathrm{C}$ for $20 \mathrm{~min}$. Following incubation with $2 \%$ FBS in PBS for $1 \mathrm{~h}$, the cells were stained with rabbit monoclonal antibody against alpha-tubulin (1:300; Epitomics, Burlingame, CA, USA) at $4^{\circ} \mathrm{C}$ for $12 \mathrm{~h}$. Subsequent to washing with PBS three times, the slides were incubated with FITC-conjugated anti-rabbit immunoglobulin (Ig)G (Proteintech group, Inc., Chicago, IL, USA) at room temperature for $1 \mathrm{~h}$. DNA was stained with DAPI at room temperature for $5 \mathrm{~min}$ and slides were analyzed by fluorescence microscopy using an Olympus CKX41 inverted microscope (Olympus, Tokyo, Japan). 

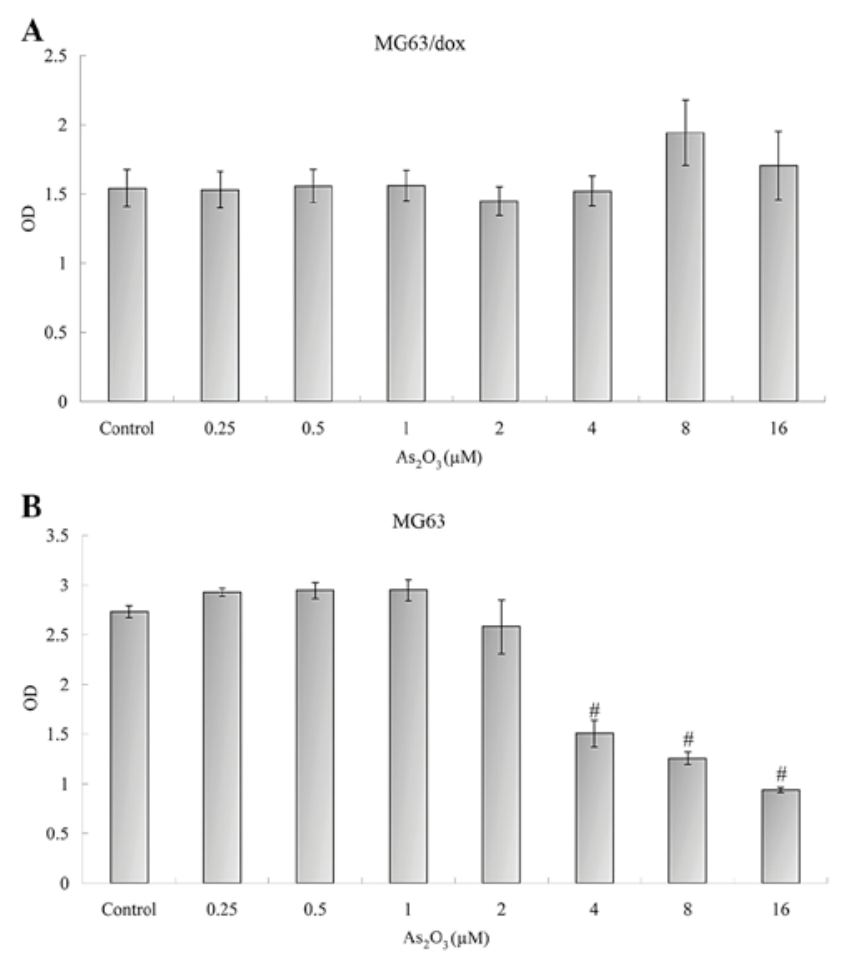

Figure 1. Effect of $\mathrm{As}_{2} \mathrm{O}_{3}$ on (A) MG63 and (B) MG63/dox human osteosarcoma cell proliferation. Cells were treated with various concentrations of $\mathrm{As}_{2} \mathrm{O}_{3}$ and incubated for $48 \mathrm{~h}$. Cell growth was markedly inhibited at 4 , 8 and $16 \mu \mathrm{M}$ doses $\left({ }^{\#} \mathrm{P}<0.01\right.$ vs. control group). Values are expressed as the mean \pm standard deviation. OD, optical density.

siRNA transient transfection. The cells were plated in six-well plates at $3 \times 10^{5}$ cells per well and cultured overnight to achieve $50-70 \%$ confluence prior to transfection. The respective siRNA molecules, namely stathmin sense, 5'-GUGUUGGUCUUUCUAAUGU-3'; negative control sense, 5'-CCUACGCCACCAAUUUCGU-3'; and positive control GAPDH sense, 5'-GUGUGAACCAUGAGAAGUA-3' were transfected into the cells with Lipofectamine 2000 transfection reagent (Invitrogen Life Technologies) according to the manufacturer's instructions. The cells were harvested at $48 \mathrm{~h}$ post transfection for PCR and western blot analysis.

Statistical analysis. Values are representative of triplicate determinations in two or more experiments and statistical analyses were performed with SPSS software version 17.0 (SPSS, Inc., Chicago, IL, USA). The results are presented as the mean \pm standard deviation. $\mathrm{P}<0.05$ was considered to indicate a statistically significant difference.

\section{Results}

Effect of $\mathrm{As}_{2} \mathrm{O}_{3}$ and $A D M$ on parental MG63 and MG63/dox cell proliferation. To confirm that $\mathrm{As}_{2} \mathrm{O}_{3}$ and $\mathrm{ADM}$ combination treatment inhibited cell growth, the parental MG63 cells and the resistant MG63/dox cells were quantified using the CCK-8 assay. $\mathrm{As}_{2} \mathrm{O}_{3}$ alone did not inhibit MG63 or MG63/dox cell proliferation effectively at any of the various doses (Fig. 1A), but $\mathrm{As}_{2} \mathrm{O}_{3}$ was effective in significantly inhibiting the growth of MG63 cells at 4,8 and $16 \mu \mathrm{M}$ concentrations ( $\mathrm{P}<0.01$, Fig. 1B).
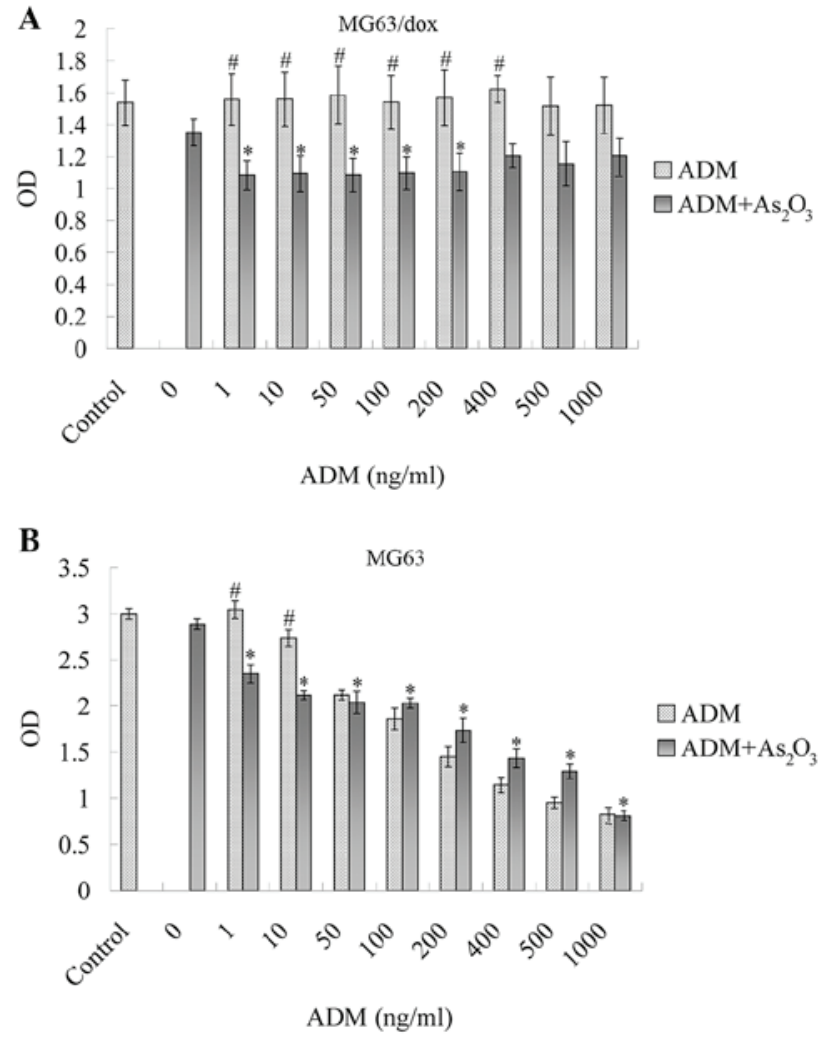

Figure 2. Effect of $\mathrm{As}_{2} \mathrm{O}_{3}$ and $\mathrm{ADM}$ combination treatment on (A) MG63 and (B) MG63/dox human osteosarcoma cells. Cells were treated with $2 \mu \mathrm{M} \mathrm{As}_{2} \mathrm{O}_{3}$ and various concentrations of ADM, and incubated for $48 \mathrm{~h}$. (A) Combination treatment inhibited cell proliferation significantly compared with the control at 1, 10, 50, 100 and $200 \mathrm{ng} / \mathrm{ml} \mathrm{ADM} \mathrm{(} \mathrm{P}<0.05)$. In contrast to ADM alone, combination treatment inhibited cell proliferation distinctly at 1, 10, 50, 100, 200 and $400 \mathrm{ng} / \mathrm{ml}$ concentrations $\left({ }^{\sharp} \mathrm{P}<0.05\right)$. (B) Combination treatment at various concentrations inhibited cell proliferation significantly compared with the control $\left({ }^{*} \mathrm{P}<0.05\right)$, and reduced cell growth at 1 and $10 \mathrm{ng} / \mathrm{ml}$ doses compared with ADM alone ( $\left({ }^{\mathrm{P}}<0.05\right)$. The combined inhibitory effect declined at high doses of ADM. ADM, doxorubicin; OD, optical density.

As a cytotoxic drug, $\mathrm{As}_{2} \mathrm{O}_{3}$ may produce severe side effects in patients at increasing dosages or extended treatment durations. The practical dose of $\mathrm{As}_{2} \mathrm{O}_{3}$ in clinical therapy conversed to the laboratory research should be $0.5-2 \mu \mathrm{M}$, and therefore, $2 \mu \mathrm{M}$ was selected as the dose of $\mathrm{As}_{2} \mathrm{O}_{3}$ in the follow-up experiments (10).

In contrast to the various concentrations of $\mathrm{ADM}$ alone, the combination of $2 \mu \mathrm{M} \mathrm{As}_{2} \mathrm{O}_{3}$ with varying doses of ADM between 1 and $1,000 \mathrm{ng} / \mathrm{ml}$ resulted in a significant reduction in the growth of MG63/dox cells ( $\mathrm{P}<0.05$, Fig. 2A). Although combination treatment also significantly restrained the growth of MG63 cells compared with that of the control group $(\mathrm{P}<0.05)$, the addition of $\mathrm{As}_{2} \mathrm{O}_{3}$ reduced the inhibitory effect of ADM at 50, 100, 200, 400, 500 and $1,000 \mathrm{ng} / \mathrm{ml}$ doses (Fig. 2B). The results demonstrated that combination treatment with $\mathrm{As}_{2} \mathrm{O}_{3}$ and $\mathrm{ADM}$ was effective in inhibiting the growth of MDR osteosarcoma cells.

Effect of $\mathrm{As}_{2} \mathrm{O}_{3}$ and $A D M$ on $M G 63 /$ dox cell cycle. Analysis of the cell-cycle phase distribution was conducted to investigate the antiproliferative mechanism of $\mathrm{As}_{2} \mathrm{O}_{3}$ and $\mathrm{ADM}$ on MG63/dox cells. The results revealed significant differences 
Table I. Effect of $\mathrm{As}_{2} \mathrm{O}_{3}$ and ADM on MG63/dox cell cycle distribution.

\begin{tabular}{lccr}
\hline Treatment & G0/G1 phase $(\%)$ & S phase $(\%)$ & G2/M phase $(\%)$ \\
\hline Control & $67.3 \pm 0.19$ & $21.2 \pm 0.08$ & $11.6 \pm 0.23$ \\
$\mathrm{ADM}(200 \mathrm{ng} / \mathrm{ml})$ & $68.2 \pm 0.12$ & $19.2 \pm 0.33$ & $12.6 \pm 0.45$ \\
$\mathrm{As}_{2} \mathrm{O}_{3}(2 \mu \mathrm{M})$ & $53.9 \pm 0.15$ & $24.7 \pm 0.18$ & $21.4 \pm 0.32$ \\
$\mathrm{As}_{2} \mathrm{O}_{3}$ and $\mathrm{ADM}$ & $20.7 \pm 0.19^{\mathrm{a}}$ & $24.1 \pm 0.09^{\mathrm{a}}$ & $55.2 \pm 0.26^{\mathrm{a}}$
\end{tabular}

Values are presented as the mean \pm standard deviation of three experiments. ${ }^{\mathrm{a}} \mathrm{P}<0.01$ as compared with the control group. ADM, doxorubicin.

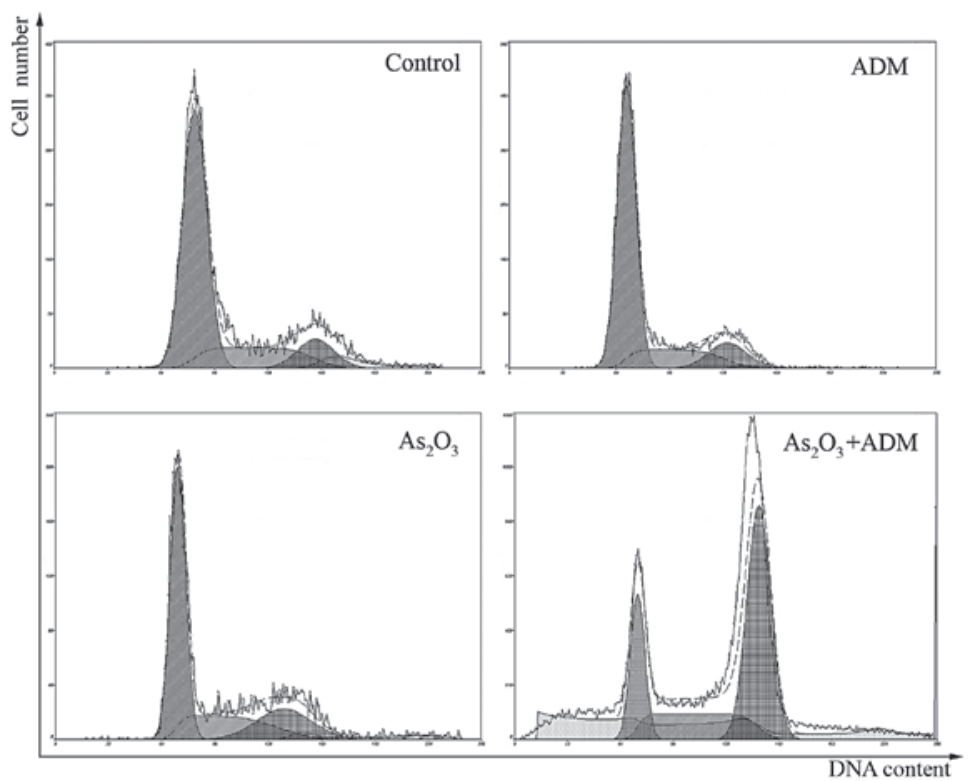

Figure 3. Effect of $48 \mathrm{~h} \mathrm{As}_{2} \mathrm{O}_{3}(2 \mu \mathrm{M})$ and ADM $(200 \mathrm{ng} / \mathrm{ml})$ treatment on the cell cycle of MG63/dox human osteosarcoma cells. Increases in the fraction of cells in the $\mathrm{G} 2 / \mathrm{M}$ phase following $\mathrm{As}_{2} \mathrm{O}_{3}$ and $\mathrm{ADM}$ combination treatment were detected, with a concurrent reduction in the numbers of cells in the G0/G1 phase. ADM, doxorubicin.

in the percentages of combination treatment cells in each cell cycle phase compared with the control cells $(\mathrm{P}<0.01$; Fig. 3 and Table I). Increases in the fraction of cells in the $\mathrm{G} 2 / \mathrm{M}$ phase were detected following $\mathrm{As}_{2} \mathrm{O}_{3}$ and ADM treatment, and a concurrent reduction of the cell proportion in G0/G1 phase was observed. The results demonstrated that $\mathrm{As}_{2} \mathrm{O}_{3}$ and ADM combination treatment inhibited the proliferation of MG63/dox cells through cell cycle arrest at the $\mathrm{G} 2 / \mathrm{M}$ phase.

Induction of apoptosis in MG63/dox cells by ADM and $\mathrm{As}_{2} \mathrm{O}_{3} . \mathrm{As}_{2} \mathrm{O}_{3}$ has been reported to induce apoptosis in various human cancer cells (10). To determine whether $\mathrm{As}_{2} \mathrm{O}_{3}$ induced apoptosis in MG63/dox cells, the cells were treated with $\mathrm{As}_{2} \mathrm{O}_{3}$ and $\mathrm{ADM}$ for $48 \mathrm{~h}$. The results of flow cytometric analysis with Annexin V-PI staining revealed that $\mathrm{ADM}$ or $\mathrm{As}_{2} \mathrm{O}_{3}$ treatment alone did not induce apoptosis; however, $\mathrm{ADM}$ and $\mathrm{As}_{2} \mathrm{O}_{3}$ combination treatment increased the percentage of apoptotic cells significantly (Fig. 4).

Effect of $\mathrm{As}_{2} \mathrm{O}_{3}$ and ADM combination treatment on stathmin expression levels. Stathmin, a signal transduction regulatory factor, is crucial in cell division and malignant development.
Zhang et al (8) observed that the stathmin gene was expressed at high levels in osteosarcoma and may become a novel target in osteosarcoma treatment. In order to determine whether stathmin was involved in $\mathrm{As}_{2} \mathrm{O}_{3}$ and $\mathrm{ADM}$-induced apoptosis, MG63/dox cells were incubated with $\mathrm{As}_{2} \mathrm{O}_{3}$ and ADM for $48 \mathrm{~h}$, and stathmin expression levels were analyzed using PCR and western blotting. The results demonstrated that incubation with $\mathrm{As}_{2} \mathrm{O}_{3}$ and $\mathrm{ADM}$ resulted in significant downregulation of stathmin expression in MG63/dox cells. Treatment of the MDR cell line with $\mathrm{As}_{2} \mathrm{O}_{3}$ or ADM alone did not induce distinctly reduced stathmin expression levels (Fig. 5).

Effect of $\mathrm{As}_{2} \mathrm{O}_{3}$ and $\mathrm{ADM}$ combination treatment on the cytoskeleton and morphology of MG63/dox cells. Stathmin knockdown has been reported to alter the phenotype of microtubules. In order to validate the above finding that $\mathrm{As}_{2} \mathrm{O}_{3}$ and $\mathrm{ADM}$ combined treatment downregulated stathmin expression, the cell microtubule network was examined by immunofluorescent imaging of cells treated with $\mathrm{As}_{2} \mathrm{O}_{3}$ and ADM (Fig. 6). Distinguished cell morphological changes were observed using staining conditions and counting all cells within multiple images. In particular, the cells treated with ADM 

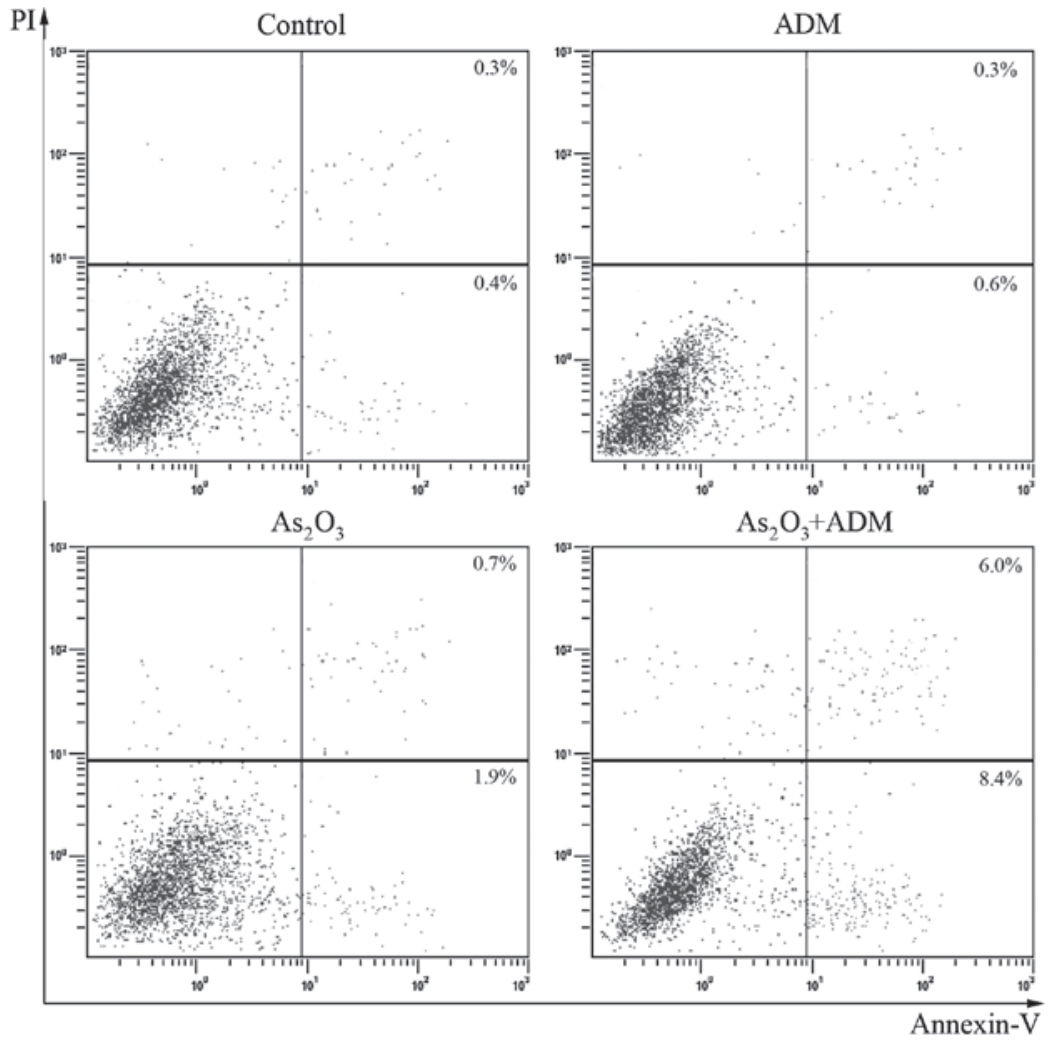

Figure 4. $\mathrm{As}_{2} \mathrm{O}_{3}$ and ADM induced apoptosis in MG63/dox human osteosarcoma cells. The cells were treated with $\mathrm{As}_{2} \mathrm{O}_{3}$ and $\mathrm{ADM}$ for $48 \mathrm{~h}$. Cell apoptosis was detected by flow cytometry with Annexin V-fluorescein isothiocyanate/PI dual staining. Results are expressed as the percentage of apoptotic cells in early (bottom right) and late (top right) apoptosis. $\mathrm{As}_{2} \mathrm{O}_{3}$, arsenic trioxide; $\mathrm{ADM}$, doxorubicin; PI, propidium iodide.

and $\mathrm{As}_{2} \mathrm{O}_{3}$ exhibited increased numbers of short neurite-like extensions compared with the controls. Treatment of the cells with $\mathrm{As}_{2} \mathrm{O}_{3}$ or $\mathrm{ADM}$ alone induced marginal changes in the cytoskeleton and morphology. These data indicated that $\mathrm{As}_{2} \mathrm{O}_{3}$ and ADM markedly altered the organization of microtubule networks through stathmin downregulation.

Effect of RNA interference targeting stathmin on stathmin expression levels, cell proliferation and apoptosis. To further investigate the role of stathmin in $\mathrm{As}_{2} \mathrm{O}_{3}$ and ADM-induced apoptosis, siRNA targeting stathmin was used to analyze the potential of these novel therapeutic targets in the treatment of human osteosarcoma. PCR and western blot analysis were used to determine the effect of siRNA treatment on stathmin mRNA and protein expression levels in MG63/dox cells. As shown in Fig. 7, western blotting indicated that the expression levels of stathmin protein in MG63/dox cells were significantly reduced by stathmin-siRNA. The fold change in stathmin siRNA transcript levels between the cells transfected with stathmin-siRNA and the control cells was calculated using the $2^{-\Delta \Delta \mathrm{Ct}}$ method (where $\Delta$ cycle threshold $(\mathrm{Ct})=\mathrm{Ct}_{\text {siRNA }}-\mathrm{Ct}_{\mathrm{Actin}}$ and $\Delta \Delta \mathrm{Ct}=\Delta \mathrm{Ct}_{\text {indicated group }}$ $\left.\Delta C t_{\text {control }}\right)$, and $\sim 85.5 \%$ stathmin gene expression was found to be inhibited following stathmin-siRNA transfection (Table II). These results demonstrated that siRNA sequences targeting the stathmin gene were effective in knocking down stathmin gene expression.

To analyze whether $\mathrm{As}_{2} \mathrm{O}_{3}$ reversed drug resistance through stathmin inhibition, stathmin-siRNA-transfected MG63/dox
A

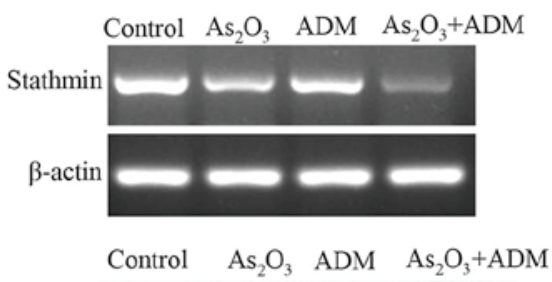

B

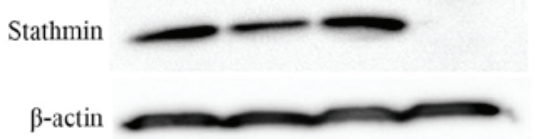

Figure 5. Exposure to $\mathrm{As}_{2} \mathrm{O}_{3}$ and ADM for $48 \mathrm{~h}$ reduced stathmin expression levels in MG63/dox human osteosarcoma cells. (A) Stathmin gene expression levels were determined by polymerase chain reaction. (B) Western blotting was employed to detect stathmin protein expression levels. The blot was also probed with an anti- $\beta$-actin monoclonal antibody to assess the relative protein levels in the sample lanes. ADM, doxorubicin.

cells were incubated with $2 \mu \mathrm{M} \mathrm{As}_{2} \mathrm{O}_{3}$ and various concentrations of ADM for $48 \mathrm{~h}$, and quantified by CCK- 8 assay. Compared with the control cells, stathmin-siRNA-transfected cells exhibited significantly enhanced chemosensitivity, increasing the inhibitory rate of $\mathrm{As}_{2} \mathrm{O}_{3}$ and $\mathrm{ADM}$ treatment by $12.77 \%$ (at $200 \mathrm{ng} / \mathrm{ml} \mathrm{ADM}$ ) to $18.91 \%$ (at $1,000 \mathrm{ng} / \mathrm{ml} \mathrm{ADM}$; Fig. 8). The effect of $\mathrm{As}_{2} \mathrm{O}_{3}$ and $\mathrm{ADM}$ administration on inducing apoptosis was also detected in the stathmin-siRNA-transfected MG63/dox cells. As shown in Fig. 9, a higher apoptotic rate was demonstrated in stathmin-siRNA-transfected cells compared 


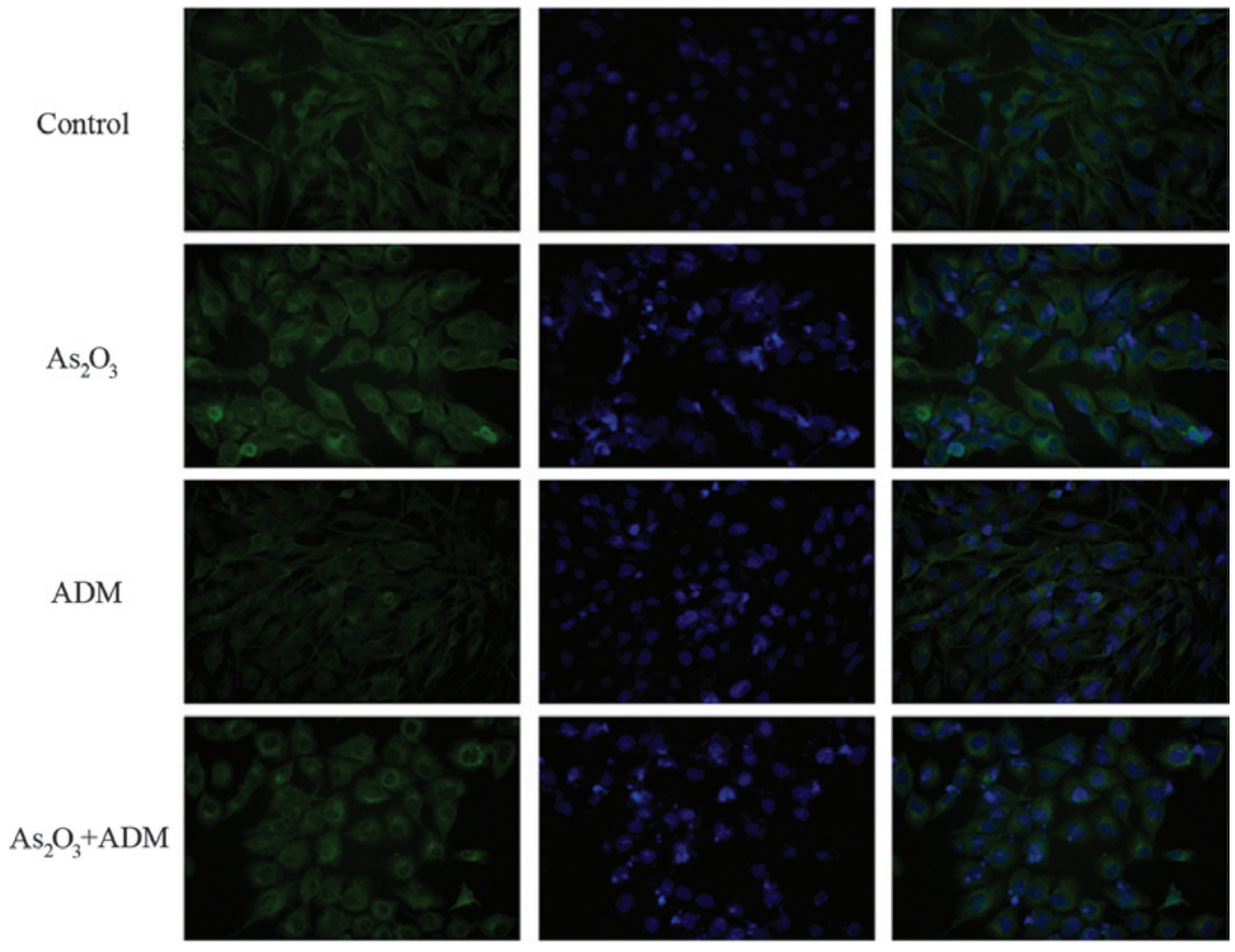

Figure 6. Effect of $\mathrm{As}_{2} \mathrm{O}_{3}$ and ADM on the microtubule network of MG63/dox human osteosarcoma cells. Slide-cultured MG63/dox cells were incubated with $200 \mathrm{ng} / \mathrm{ml} \mathrm{ADM}$ and/or $2 \mu \mathrm{M} \mathrm{As}_{2} \mathrm{O}_{3}$. At $48 \mathrm{~h}$ after incubation, cells were fixed in $4 \%$ paraformaldehyde and stained with anti- $\alpha$-tubulin antibody and DAPI. The images show microtubules in green (left row), nuclei in blue (middle row) and the merged images (right row). ADM, doxorubicin.

Table II. Stathmin and $\beta$-actin Ct values in the control and stathmin-siRNA transfected cells.

\begin{tabular}{lcc}
\hline Sample & Ct stathmin & Ct $\beta$-actin \\
\hline Control & 18.93604 & 14.72279 \\
Stathmin-siRNA & 21.95575 & 14.95309 \\
\hline
\end{tabular}

Ct, cycle threshold; siRNA, small interfering RNA. The fold change of stathmin siRNA transcript levels between stathmin-siRNA group and the control equals $85.5 \%$ (via $2^{-\Delta \Delta C t}$ ).

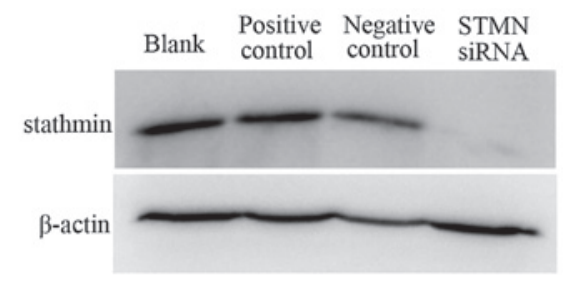

Figure 7. Expression levels of STMN protein in transfected MG63/dox human osteosarcoma cells detected by Western blot analysis. STMN immunoreactive bands were normalized to $\beta$-actin bands on the same membrane. STMN, stathmin; siRNA, small interfering RNA.

with MG63/dox cells following $\mathrm{As}_{2} \mathrm{O}_{3}$ and ADM treatment. The above results indicated that $\mathrm{As}_{2} \mathrm{O}_{3}$ and $\mathrm{ADM}$ suppressed cell proliferation and induced apoptosis, possibly through inhibiting stathmin expression.

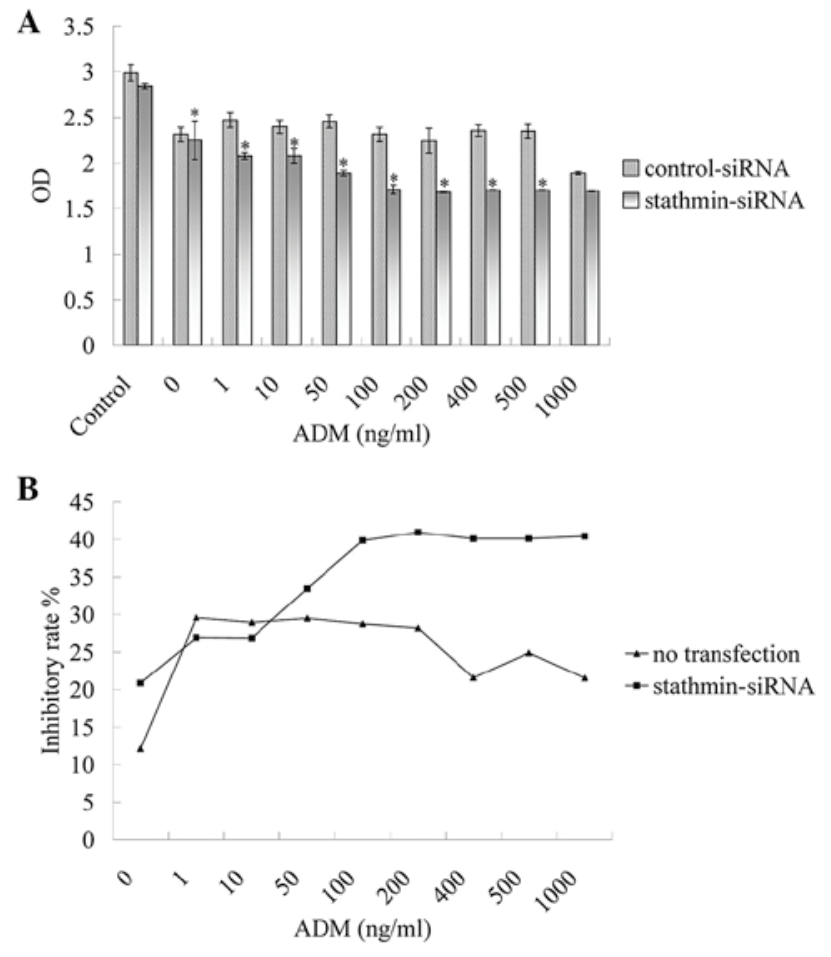

Figure 8. Effect of $\mathrm{As}_{2} \mathrm{O}_{3}$ and $\mathrm{ADM}$ combination treatment on stathmin-siRNA-transfected MG63/dox human osteosarcoma cells. (A) Stathmin-siRNA and control-siRNA-transfected MG63/dox cells were treated with $2 \mu \mathrm{M} \mathrm{As}_{2} \mathrm{O}_{3}$ and various concentrations of ADM. After $48 \mathrm{~h}$ incubation, cell growth was evaluated by the cell counting kit- 8 assay ( $\mathrm{P}<0.05$ vs. control group). (B) Stathmin-siRNA enhanced the cytotoxic effect of $\mathrm{As}_{2} \mathrm{O}_{3}$ and ADM. ADM, doxorubicin; siRNA, small interfering RNA; OD, optical density. 


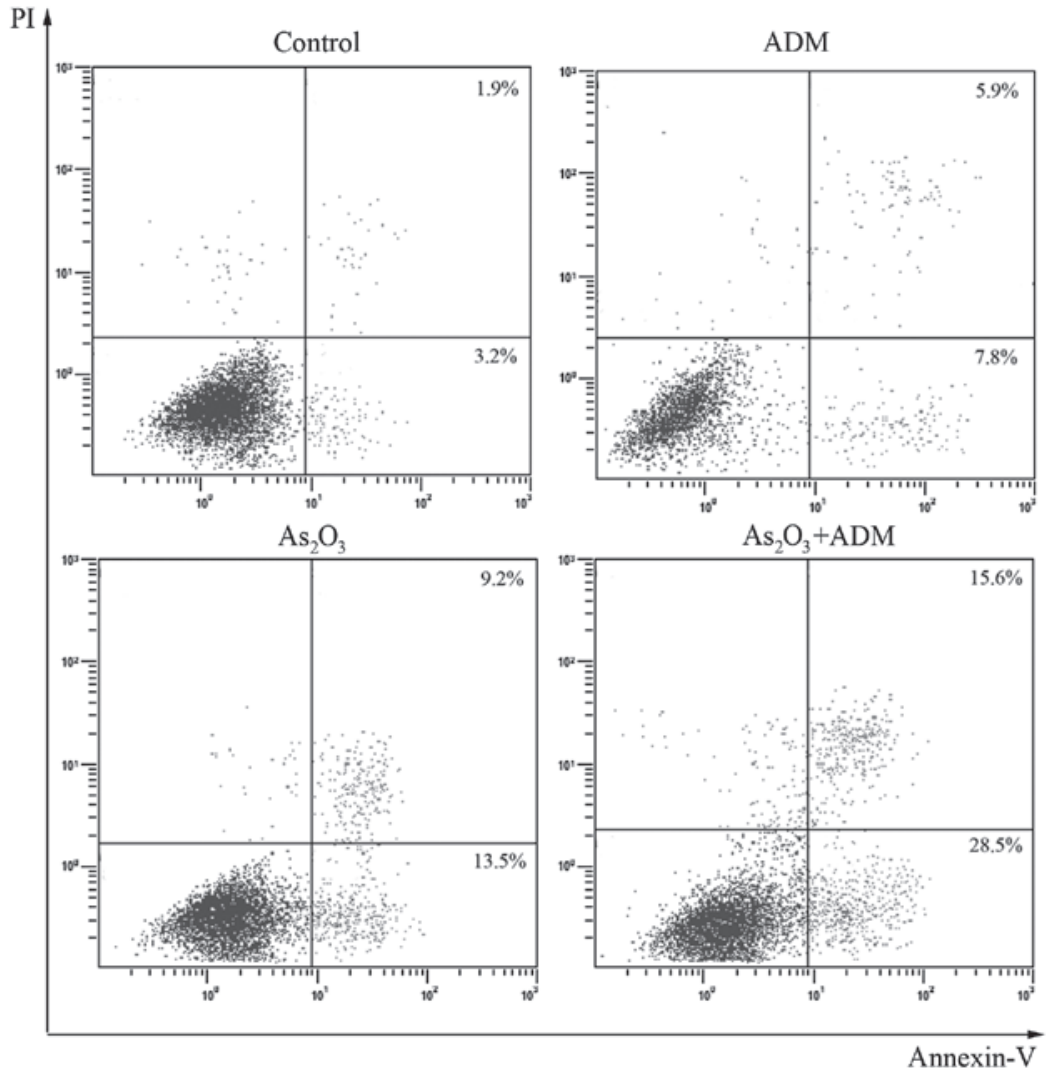

Figure 9. $\mathrm{As}_{2} \mathrm{O}_{3}$ and ADM induce apoptosis in stathmin-siRNA transfected MG63/dox human osteosarcoma cells. The transfected MG63/dox cells were treated with $2 \mu \mathrm{M} \mathrm{As}_{2} \mathrm{O}_{3}$ and $200 \mathrm{ng} / \mathrm{ml}$ ADM for $48 \mathrm{~h}$. Cell apoptosis was detected by flow cytometry with Annexin V-fluorescein isothiocyanate/PI dual staining. Results are expressed as percentage of apoptotic cells in early and late apoptosis. ADM, doxorubicin; PI, propidium iodide; siRNA, small interfering RNA.

\section{Discussion}

Osteosarcoma is the most common type of primary malignant bone tumor in children and adolescents; $\sim 60 \%$ of primary malignant bone tumors are diagnosed in the first two decades of life (11). With the introduction of intensive chemotherapeutics, including cisplatin, doxorubicin, ifosphamide and high dose methotrexate, $>60 \%$ of the patients are cured (1). However, $30-40 \%$ patients with localized osteosarcoma experience recurrent or progressive disease. The majority of these patients are considered to have MDR osteosarcoma cancer cells, resistant to one or more chemotherapeutic agents (12). Resistance to these agents remains a challenge in the treatment of osteosarcoma and an obstacle to achieving improved cure rates. Thus, novel drugs and therapeutic regimens are required for more effective treatment of aggressive and recurrent MDR osteosarcoma.

$\mathrm{As}_{2} \mathrm{O}_{3}$-based compounds are the most widely used and analyzed arsenic-based cancer drugs. Results of in vitro studies and clinical trials have revealed that $\mathrm{As}_{2} \mathrm{O}_{3}$ is effective in inhibiting the growth of APL cells (3). Recent studies have found that $\mathrm{As}_{2} \mathrm{O}_{3}$ also exhibits an anticancer effect in particular types of non-APL cancer, including myeloid leukemia, gastric cancer, prostate and ovarian carcinomas, and breast cancer (5). However, studies regarding the effect of $\mathrm{As}_{2} \mathrm{O}_{3}$ on osteosarcoma are rare. According to a study by Guo et al (13), $\mathrm{As}_{2} \mathrm{O}_{3}$ combined with VP-16 and paclitaxel was an effective remedy in the treatment of stage III osteosarcoma. A previous study also revealed that $\mathrm{As}_{2} \mathrm{O}_{3}$ induced apoptosis in MG63 human osteosarcoma cells (14). These findings prompted the investigation of the effect of $\mathrm{As}_{2} \mathrm{O}_{3}$ on MDR human osteosarcoma cells in the present study. $\mathrm{As}_{2} \mathrm{O}_{3}$ has been reported to downregulate P-glycoprotein expression in human leukemia cells (15). In the present study, the MG63/dox MDR osteosarcoma cell line, which is characterized by upregulation of the MDR1 gene and overexpression of P-glycoprotein, was used.

The results revealed that combination treatment with $\mathrm{As}_{2} \mathrm{O}_{3}$ and ADM was effective in inhibiting MG63 and MG63/dox cell proliferation. The MG63/dox drug-resistant cells exhibited particular sensitivity to the combination treatment. Furthermore, the combination treatment induced MG63/dox apoptosis and cell-cycle arrest. This finding is of great importance for evaluating the potential use of $\mathrm{As}_{2} \mathrm{O}_{3}$ in treating patients with MDR.

A growing number of studies have reported that stathmin was expressed at high levels in a wide variety of human malignancies, including osteosarcoma. Stathmin is a key regulator of the microtubule network and provides an attractive therapeutic target in cancer treatment (6). High levels of stathmin expression in cancer cells were observed to correlate with cell proliferative potential and appear to be required for the maintenance of the malignant phenotype (16).

The present study provided evidence that stathmin may be involved in $\mathrm{As}_{2} \mathrm{O}_{3}$-induced MDR cell apoptosis. $\mathrm{As}_{2} \mathrm{O}_{3}$ and ADM treatment not only inhibited MG63/dox cell proliferation and induced apoptosis, but also resulted in reduced stathmin expression levels, indicating that reduced stathmin expression levels are associated with $\mathrm{As}_{2} \mathrm{O}_{3}$ and $\mathrm{ADM}$-induced apoptosis. Furthermore, treatment with $\mathrm{As}_{2} \mathrm{O}_{3}$ and ADM altered the 
cytoskeleton of MG63/dox cells, while stathmin knockdown has been reported to alter the phenotype of microtubules. These results demonstrated that stathmin may be crucial in the reversion of drug resistance by $\mathrm{As}_{2} \mathrm{O}_{3}$.

To demonstrate the possible role of stathmin in the $\mathrm{As}_{2} \mathrm{O}_{3}$-induced apoptotic pathway, siRNA targeting stathmin was transfected into MG63/dox cells. The CCK-8 assay demonstrated that the combination treatment inhibited the transfected MG63/dox cell proliferation markedly compared with the non-transfection group. Flow cytometric analysis revealed that the treatment with $\mathrm{As}_{2} \mathrm{O}_{3}$ and $\mathrm{ADM}$ induced marked apoptosis. Stathmin is a ubiquitous cytoplasmic phosphoprotein that regulates microtubule dynamics. Inhibiting stathmin expression may influence the functions of either centrosomes or G2/M checkpoint proteins at the centrosome, which may result in a $\mathrm{G} 2 / \mathrm{M}$ block and reduce the rate of cell proliferation (17). In the present study, stathmin was demonstrated to be involved in $\mathrm{As}_{2} \mathrm{O}_{3}$-induced apoptosis in human osteosarcoma cells and this finding may support the use of stathmin as a therapeutic target in human osteosarcomas. The exact molecular mechanism that accounts for the observed interaction between stathmin inhibition and $\mathrm{As}_{2} \mathrm{O}_{3}$ treatment appears complex and requires further clarification.

In conclusion, the administration of $\mathrm{As}_{2} \mathrm{O}_{3}$ together with ADM may be a useful novel anticancer chemotherapy, particularly in MDR cases, as $\mathrm{As}_{2} \mathrm{O}_{3}$ reversed $\mathrm{ADM}$ resistance in MG63/dox cells through downregulation of stathmin. The results indicated that $\mathrm{As}_{2} \mathrm{O}_{3}$ is a promising chemotherapeutic agent for patients with drug-resistant osteosarcoma.

\section{Acknowledgements}

This study was supported by the National Natural Science Foundation of China (grant no. 81172105).

\section{References}

1. Serra M, Scotlandi K, Manara MC, et al: Establishment and characterization of multidrug-resistant human osteosarcoma cell lines. Anticancer Res 13: 323-329, 1993.
2. Rajkumar T and Yamuna M: Multiple pathways are involved in drug resistance to doxorubicin in an osteosarcoma cell line. Anticancer Drugs 19: 257-265, 2008.

3. Rego EM, He LZ, Warrell RP Jr, et al: Retinoic acid (RA) and $\mathrm{As}_{2} \mathrm{O}_{3}$ treatment in transgenic models of acute promyelocytic leukemia (APL) unravel the distinct nature of the leukemogenic process induced by the PML-RARalpha and PLZF-RARalpha oncoproteins. Proc Natl Acad Sci USA 97: 10173-10178, 2000.

4. Bachleitner-Hofmann T, Kees M and Gisslinger H: Arsenic trioxide: acute promyelocytic leukemia and beyond. Leuk Lymphoma 43: 1535-1540, 2002.

5. Miller WH Jr, Schipper HM, Lee JS, et al: Mechanisms of action of arsenic trioxide. Cancer Res 62: 3893-3903, 2002.

6. Niethammer P, Bastiaens P and Karsenti E: Stathmin-tubulin interaction gradients in motile and mitotic cells. Science 303: 1862-1866, 2004.

7. Rubin CI and Atweh GF: The role of stathmin in the regulation of the cell cycle. J Cell Biochem 93: 242-250, 2004.

8. Zhang HZ, Wang Y, Gao P, et al: Silencing stathmin gene expression by survivin promoter-driven siRNA vector to reverse malignant phenotype of tumor cells. Cancer Biol Ther 5: 1457-1461, 2006.

9. Wang R, Dong K, Lin F, et al: Inhibiting proliferation and enhancing chemosensitivity to taxanes in osteosarcoma cells by RNA interference-mediated downregulation of stathmin expression. Mol Med 13: 567-575, 2007.

10. Ling YH, Jiang JD, Holland JF and Perez-Soler R: Arsenic trioxide produces polymerization of microtubules and mitotic arrest before apoptosis in human tumor cell lines. Mol Pharmacol 62: 529-538, 2002.

11. Schwartz CL, Gorlick R, Teot L, et al; Children's Oncology Group: Multiple drug resistance in osteogenic sarcoma: INT0133 from the Children's Oncology Group. J Clin Oncol 25: 2057-2062, 2007.

12. Mimeault M, Hauke R, Mehta PP, et al: Recent advances on the molecular mechanisms involved in the drug resistance of cancer cells and novel targeting therapies. J Cell Mol Med 11: 981-1011, 2007.

13. Guo W, Tang XD, Tang S and Yang Y: Preliminary report of combination chemotherapy including Arsenic trioxide for stage III osteosarcoma and Ewing sarcoma. Zhonghua Wai Ke Za Zhi 44: 805-808, 2006 (In Chinese).

14. Xiao T, Li KH and Fang JZ: Experimental study on the apoptotic effect of arsenic trioxide on human osteosarcoma MG-63 cells. Hunan Yi Ke Da Xue Xue Bao 27: 111-113, 2002 (In Chinese).

15. Wei H, Su H, Bai D, et al: Arsenic trioxide inhibits p-glycoprotein expression in multidrug-resistant human leukemia cells that overexpress the MDR1 gene. Chin Med J (Engl) 116: 1644-1648, 2003.

16. Belmont LD and Mitchison TJ: Identification of a protein that interacts with tubulin dimers and increases the catastrophe rate of microtubules. Cell 84: 623-631, 1996.

17. Mistry SJ and Atweh GF: Stathmin inhibition enhances okadaic acid-induced mitotic arrest: a potential role for stathmin in mitotic exit. J Biol Chem 276: 31209-31215, 2001. 